\title{
Possible Influence of the Cultivated Land Reclamation on Surface Climate in India: A WRF Model Based Simulation
}

\author{
Yi Qu, ${ }^{1,2,3}$ Feng Wu, ${ }^{4}$ Haiming Yan, ${ }^{4}$ Bangrong Shu, ${ }^{5}$ and Xiangzheng Deng ${ }^{1,3}$ \\ ${ }^{1}$ Institute of Geographic Sciences and Natural Resources Research, Chinese Academy of Sciences, Beijing 100101, China \\ ${ }^{2}$ University of Chinese Academy of Sciences, Beijing 10049, China \\ ${ }^{3}$ Center for Chinese Agricultural Policy, Chinese Academy of Sciences, Beijing 100101, China \\ ${ }^{4}$ State Key Laboratory of Water Environment Simulation, School of Environment, Beijing Normal University, \\ Beijing 100875, China \\ ${ }^{5}$ School of Geodesy and Geomatics, Jiangsu Normal University, Xuzhou 221116, China
}

Correspondence should be addressed to Xiangzheng Deng; dengxz.ccap@gmail.com

Received 7 July 2013; Accepted 23 October 2013

Academic Editor: Burak Güneralp

Copyright (C) 2013 Yi Qu et al. This is an open access article distributed under the Creative Commons Attribution License, which permits unrestricted use, distribution, and reproduction in any medium, provided the original work is properly cited.

Land use/cover change (LUCC) has become one of the most important factors for the global climate change. As one of the major types of LUCC, cultivated land reclamation also has impacts on regional climate change. Most of the previous studies focused on the correlation and simulation analysis of historical LUCC and climate change, with few explorations for the impacts of future LUCC on regional climate, especially impacts of the cultivated land reclamation. This study used the Weather Research and Forecasting (WRF) model to forecast the changes of energy flux and temperature based on the future cultivated land reclamation in India and then analyzed the impacts of cultivated land reclamation on climate change. The results show that cultivated land reclamation will lead to a large amount of land conversions, which will overall result in the increase in latent heat flux of regional surface as well as the decrease in sensible heat flux and further lead to changes of regional average temperature. Furthermore, the impact on climate change is seasonally different. The cultivated land reclamation mainly leads to a temperature decrease in the summer, while it leads to a temperature increase in the winter.

\section{Introduction}

The land use/cover change (LUCC) is one of the most important human activities and one of the driving forces for the global climate change [1-5]. The LUCC can alter the properties of the land surface and subsequently influence the energy and material exchange between the biosphere and atmosphere as well as the biogeochemical process and consequently exert significant influence on the regional and even global climate [6-12]. The LUCC includes not only the change of land use patterns in the same land use type [13] but also the conversion among different land use types $[14,15]$, for example, the conversion of cultivated land to built-up land [16], deforestation, and reclamation of the wasteland [17]. As human society develops, especially since the industrial revolution, LUCC plays a more and more important role in the environment [18-20]. On the one hand, the demand of built-up land has continuously increased with the acceleration of the urbanization, and a lot of cultivated land has been occupied, which makes the existing cultivated land decrease greatly $[21,22]$. On the other hand, the population growth and improvement of the living standard have put forward higher demand on the grain production [23]. People have to meet their need by making more intensive use of the existing cultivated land and meanwhile continuously reclaiming the forests [24], grassland, and wetland and even by filling in the sea to grow grain [25]. All these human activities have profoundly influenced the regional and even global climate change [5]. In order to have deeper understanding of the impacts of LUCC on the climate change, the researchers have implemented many relevant researches and reached many conclusions; for example, the deforestation will make the temperature in different latitudes decrease or increase and lead to the decline of precipitation [26-29]. Besides, the land 
use change due to the intensive agriculture also leads to the change of the precipitation $[30,31]$, and the agricultural activities such as the agricultural irrigation also influence the regional water cycle and subsequently influence the regional and global climate change $[8,32,33]$. However, the previous researches are mostly based on the correlation analysis and simulation analysis of the historical data of land use and climate change; there have been very few researches with the research focus on forecasting the possible impacts of the reclamation of cultivated land on the regional climate, which can provide significant scientific reference for decision making during the process of reclamation of cultivated land.

India is a typical region of the reclamation of cultivated land in the global LUCC, which is closely related to its national conditions. According to the fifteenth population survey in 2011, the total population of India has exceeded 1,210 billion, accounting for $17.5 \%$ of the world population and ranking second in the population all over the world. According to the changing trend of the demographic structure by country in the world, the population of India is estimated to exceed that of China in 2030 [34]. The continuous population growth has posed a great challenge to the solution of the food security, so India has increased the seeded area by the continual reclamation of cultivated land while promoting the modernization of agriculture so as to meet the domestic food demand. The large area reclamation of cultivated land leads to the land use/cover change, which inevitably influences the exchange and distribution of the energy, moisture, and momentum between the biosphere and atmosphere, affects the radiation balance and water cycle, and has significant effects on the regional climate through various biological geophysical effects [6, 27]. So what biological geophysical effects will the future large-scale reclamation of cultivated land have? What changes in the regional climate will it further lead to? This study has aimed to quantitatively project these effects by the model simulation.

The climate effect of the reclamation of cultivated land in India is one of the key research issues at the regional scale and the result of the interaction and feedback among the soil, vegetation, and atmosphere. The atmospheric general circulation models have a low simulation ability at the regional scale due to restriction of the resolution; while the land surface models cannot reveal the feedbacks between the atmosphere and land surface, the short term sensitivity tests of the mesoscale models can only be used to simulate and explain the impacts of the reclamation of cultivated land on specific weather processes and cannot reveal the longterm climatic effects [35]. So, it is necessary to predict the climatic effects of the reclamation of cultivated land in India by implementing the long-term analog integration with the high-resolution regional climate model. This study has used the latest-generation numerical weather prediction model, the Weather Research and Forecasting (WRF) model, which has a high ability to simulate the surface-atmosphere process accurately [36-38]. By integrating the future reclamation of cultivated land in India, this study has forecasted the climatic effects of the reclamation of cultivated land during 20102050 by the long-time simulation with analog integration so as to quantitatively analyze the possible impacts of the future reclamation of cultivated land in India on the regional climate.

\section{Model and Data}

2.1. Model. The WRF model is a next-generation mesoscale model developed by a group of scientists from different institutes. It includes the Advanced Research WRF (ARW) and the Nonhydrostatic Mesoscale Model (NMM); this study has adopted the former one. Besides, this study has calculated the flux of the exchange of sensible heat and latent heat between the land surface and atmosphere from the perspective of the water balance and energy balance with the Noah land surface parameterization scheme in the WRF model. The simulation domain is illustrated in Figure 1. The spatial resolution was set to be $30 \mathrm{~km}$, and there were 79 grid points in the eastwest direction and 111 grid points in the north-south direction in the whole simulation area. The eastern small part of India is not included in the study area. The temporal duration of the simulation with the WRF model is for the time period between 2010 and 2050 in this study.

The parameterization scheme mainly includes the Noah land surface parameterization scheme [39], CAM3 radiation scheme [40], WSM3-class simple ice microphysics (MP) scheme [41], Grell-Devenyi ensemble scheme for cumulus convection [42], and YSU boundary layer scheme [43]. The fifth phase of the Coupled Model Intercomparison Project (CMIP5) produces a state-of-the-art multimodel dataset designed to advance our knowledge of climate variability and climate change. The model output which is being analyzed by researchers worldwide underlies the Fifth Assessment Report by the Intergovernmental Panel on Climate Change. It provides projections of future climate change on two time scales, near term (out to about 2035) and long term (out to 2100 and beyond). Model output of the latter of Representative Concentration Pathway (RCP) 6.0 such as air temperature, specific humidity, sea level pressure, eastward wind, northward wind, and geopotential height from 2010 to 2050 was used as the atmospheric forcing dataset of WRF model.

The parameters of the Noah land surface parameterization change as the land cover conditions change, but they all change globally, so it is necessary to adjust the configuration of these parameters since India is only a region. Besides, only the vegetation parameters related to the land cover as well as the land cover change were adjusted since this study has mainly focused on the effects of the land cover change rather than the radiation process.

2.2. Data. The main data we used in our simulation are derived from the experimental designs. There are two sets of tests included in the experimental design; one is the control test and the other is the prediction test (Table 1). The land cover data in 2010 and the predicted land cover data in 2050 were used as the underlying surface data in the control test and prediction test, respectively. The land cover data in 2010 were extracted from the USGS remote sensing images deriving from the National Basic Research Program of China. 


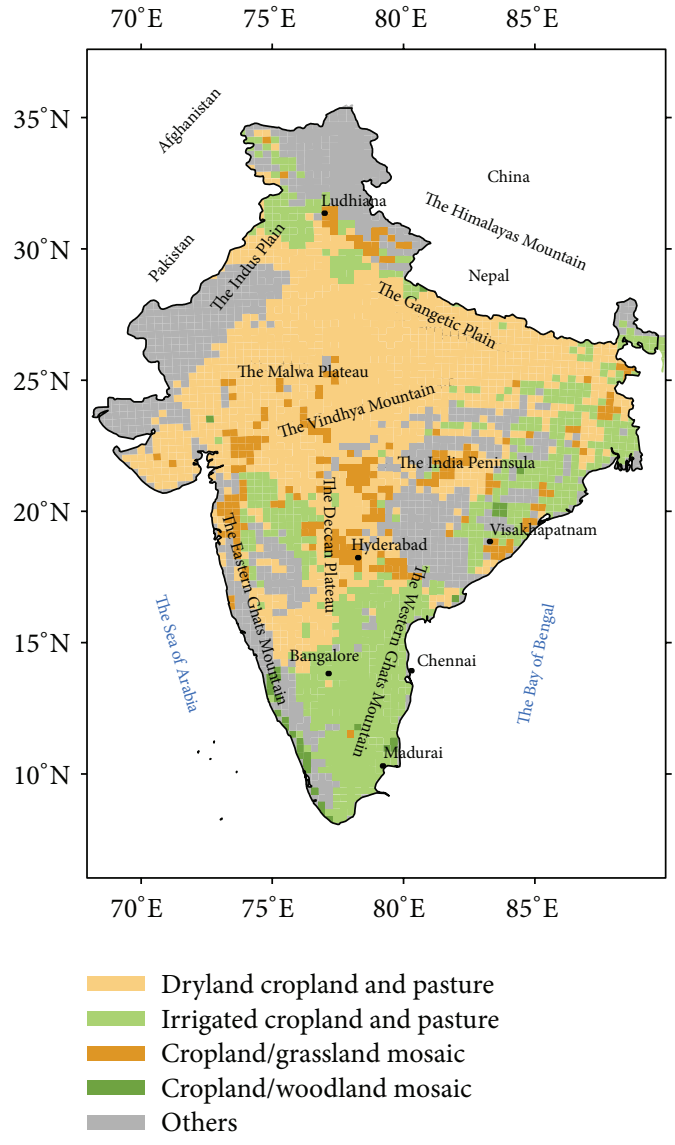

(a)

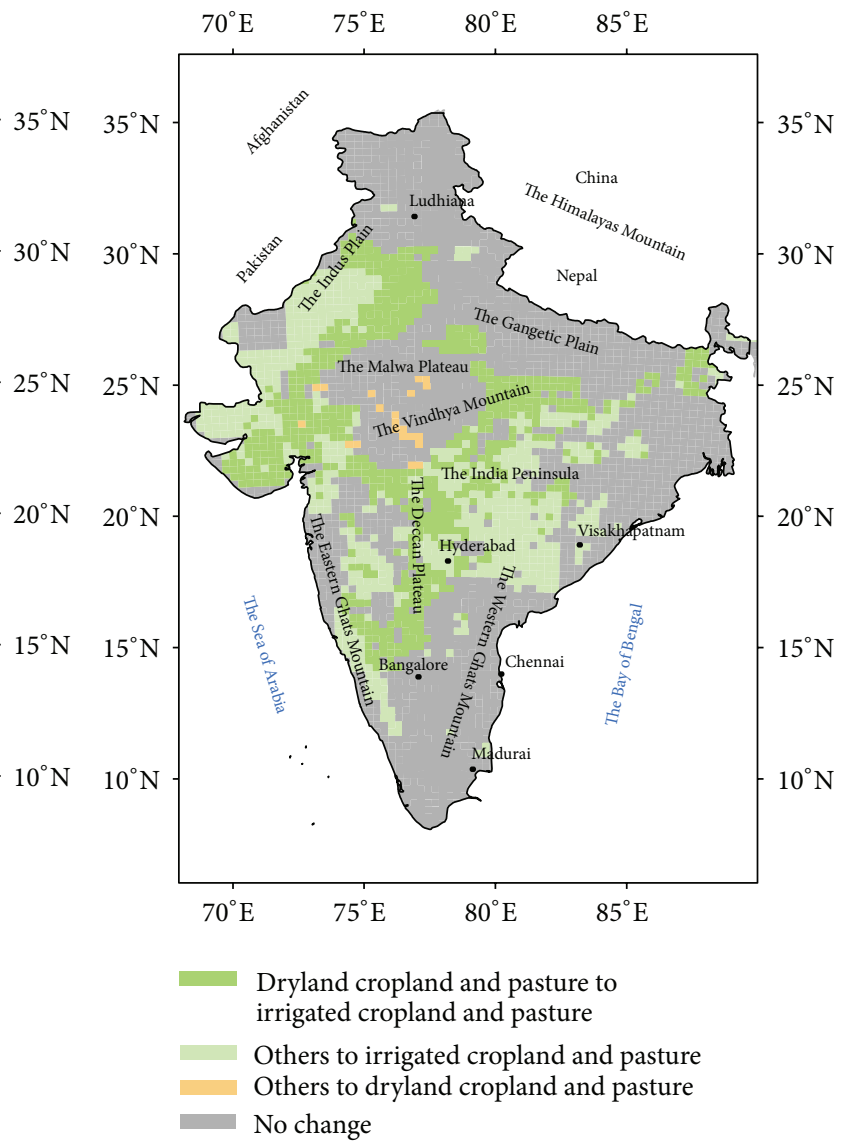

(b)

FIGURE 1: Spatial pattern of cultivated land in the base year of 2010 (a) and its possible changes in future (b) in India.

TABLE 1: Description of the experimental design.

\begin{tabular}{lccc}
\hline Test & Test period & Forcing data & Land cover data used in the WRF model \\
\hline Control test & 2050 & 2050 & Land cover data of 2050 \\
Prediction test & $2010-2050$ & $2010-2050$ & Land cover data of 2010 \\
\hline
\end{tabular}

And the predicted land cover data in 2050 were obtained by combining the data of the newly increased cultivated land (deriving from the LUCC data) and the former data. The LUCC data used to forecast the land use change during 20102050 came from the RCP 6.0 scenario developed by the Asia-Pacific Integrated Model (AIM) modeling team at the National Institute for Environmental Studies (NIES), Japan. We choose RCP 6.0 because it is a stabilization scenario where total radiative forcing is stabilized after 2100 without overshoot by employment of a range of technologies and strategies for reducing greenhouse gas emissions [44]. Only the data of newly increased cultivated land were extracted since this study mainly aimed to analyze the impacts of the reclamation of cultivated land on regional climate.

\section{Result}

3.1. Changes of the Spatial Patterns of Cultivated Land in India. Cultivated land is widely distributed in India, and the total area of the cultivated land and pasture reaches around 2.07 million $\mathrm{km}^{2}$, accounting for $73.03 \%$ of the study area. There are mainly four kinds of cultivated land in India which correspond to the USGS classification, that is, the dryland cropland and pasture, irrigated cropland and pasture, cropland/grassland mosaic, and cropland/woodland mosaic. The dryland cropland and pasture is mainly located in Gangetic Plain in the north part of India, Malwa Plateau in the middle part of India, and the northern part of Deccan Plateau. The dryland cropland and pasture owns the largest area among the four kinds of cultivated land, reaching nearly 1.18 million $\mathrm{km}^{2}$, or $56.76 \%$ of the total cultivated land area, in study area. The irrigated cropland and pasture ranks second in the total area, reaching over 665.65 thousand $\mathrm{km}^{2}$, accounting for $32.10 \%$ of the total area of cultivated land; it is mainly distributed in the northern part of Indus plain, eastern part of India Peninsula, and the coastal plain in the southern part of India. There are only a few cropland/grassland mosaics in the northern part of Indus plain and the middle part of 
India Peninsula, the area of which is around 203.66 thousand $\mathrm{km}^{2}$, accounting for $9.82 \%$ of the total cultivated land area. The cropland/woodland mosaic is kept with the least area, only reaching 27.39 thousand $\mathrm{km}^{2}$, or $1.32 \%$ of the total area of cultivated land, as is sparsely distributed in the coastal area in the southwest parts of India (Figure 1(a)).

According to the land transfer data under the AIM performance, the area of the cultivated land that will change in the future is around 1.16 million $\mathrm{km}^{2}$. There will be conversion of the cultivated land in most part of India except Gangetic Plain and the coastal area in the southeast part of India, including the conversion of other land use types into the cultivated land as well as the conversion of the dryland cropland into the irrigated cropland (Figure 1(b)). The conversion area of the dryland cropland into the irrigated cropland will be 584.33 thousand $\mathrm{km}^{2}$, or $50.23 \%$ of the total conversion area. The conversion of the dryland cropland into the irrigated cropland is mainly in regions where the terrain is flat, for example, Indus Plain and the middle part of India Peninsula, and it is mainly due to the improvement of the irrigation techniques. By contrast, the conversion of other land use types into the irrigated cropland mainly distributes in the regions except Gangetic Plain and the coastal area in the southeast part and Malwa Plateau, that is, the plain and coastal area in the northeast part of Eastern Ghats Mountain, the northern part of Western Ghats Mountain, and some undeveloped regions with certain water sources in the southwest part of India. It is mainly caused by the increasing demand for the grain due to the population growth, and the area of this kind of conversion will be up to 560.12 thousand $\mathrm{km}^{2}$, accounting for $48.15 \%$ of the total conversion area. Among the conversions of other land use types into the irrigated cropland, grassland and shrub accounts for $93 \%$, while forest only accounts for $7 \%$, only very little land of other land use types will be converted into the dryland cropland, only sparsely distributed in Malwa Plateau. There has been a large area of dryland cropland in India, and more land will be converted into the irrigated land which is of higher productivity with the improvement of the irrigation conditions, progress of irrigation techniques, and increase in the grain demand.

3.2. Verification of the Ability of the WRF Model to Simulate the Temperature Change. The ability of the WRF model to simulate the temperature change in India was first verified by comparing the simulation result of the standard WRF model and the historical data of land surface temperature. The result indicates that the maximum temperature appears around March according to both the historical data and the simulation result; besides, the minimum temperature appears in November, and the rate of temperature fall during September and November is a bit higher than the rate of temperature rise during January and March; that is, the temperature decreases a bit more rapidly in the autumn than it increased in the spring (Figure 2).

There is still some difference between the simulated and observed temperatures. The simulated temperature is lower than the observed one on the whole; the historical data

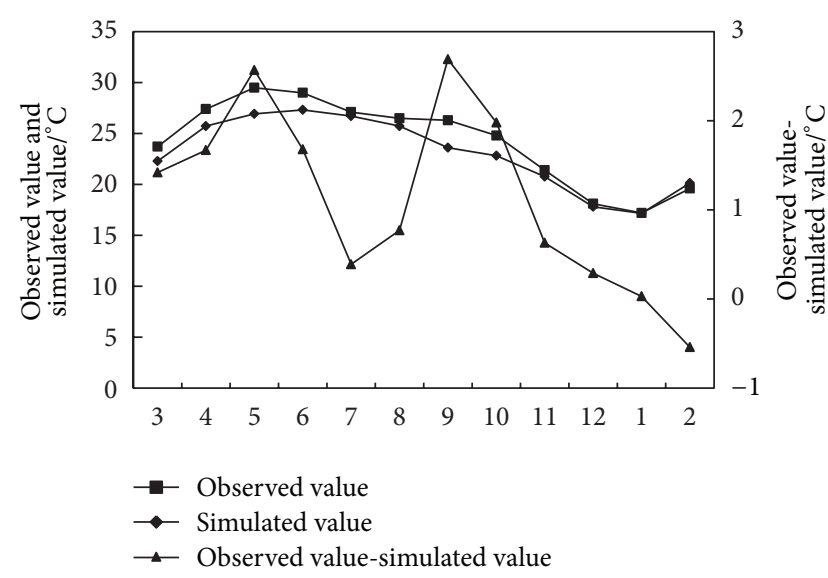

FIGURE 2: Simulated and observed values of the monthly average near-surface temperatures in India for the year of 2010. Note: The historical data come from http://sdwebx.worldbank.org/climateportal/index.cfm.

indicate the annual daily average temperature is $29.06^{\circ} \mathrm{C}$, while it is $27.70^{\circ} \mathrm{C}$ in the simulation result. As for the monthly temperature change, the simulated temperature is lower than the observed one in all months except February, and the difference between them is most significantly in September, reaching $2.69^{\circ} \mathrm{C}$. As for the seasonal temperature change, the simulated temperature is lower than the observed one in all seasons except the winter. The difference between the simulated and observed temperatures in the spring and autumn is $1.89^{\circ} \mathrm{C}$ and $1.77^{\circ} \mathrm{C}$, respectively; and it is relatively small in the summer and winter, only reaching $0.95^{\circ} \mathrm{C}$.

The spatial pattern of the annual daily average temperature indicates that the simulated and observed temperatures are both higher in the south and lower in the north and higher in the mountainous area and lower in the plain at the same latitude, and the inland is warmer than the coastal area. For example, the temperature in Madurai City in the extreme south is $20.5^{\circ} \mathrm{C}$ higher than that in Ludhiana in the extreme north; while it is $15.5^{\circ} \mathrm{C}$ higher in Bangalore City in the mountainous area than it is in Chennai City in the plain at the same latitude. Besides, the temperature in Hyderabad City in the inland is $2.4^{\circ} \mathrm{C}$ higher than that in Visakhapatnam City in the coastal area (Table 2 ).

In summary, the WRF model has a high ability to simulate the seasonal change and spatial pattern of the temperature in India, although there is some difference between the simulated and observed values, with the simulated temperature being a bit lower on the whole. The spatial pattern of the temperature indicates that there is no significant difference between the simulated and observed values in most regions except a few areas where the difference is a bit larger.

\subsection{Possible Impacts of the Cultivated Land Reclamation on the} Energy Flux. The reclamation of cultivated land in study area may lead to significant change of the energy flux, which might further influence the temperature change through the landatmosphere interaction and the change of the atmospheric circulation. Table 3 shows the projected monthly and annual 
TABLE 2: Spatial pattern of the simulated and observed values of the annual average near-surface temperature in India for the year of 2010.

\begin{tabular}{|c|c|c|c|c|c|}
\hline City & Coordinates & Location & $\begin{array}{l}\text { Observed value of } \\
\text { temperature }\left({ }^{\circ} \mathrm{C}\right)\end{array}$ & $\begin{array}{l}\text { Simulated value of } \\
\text { temperature }\left({ }^{\circ} \mathrm{C}\right)\end{array}$ & Difference $\left({ }^{\circ} \mathrm{C}\right)$ \\
\hline Ludhiana & $(31.05 \mathrm{~N}, 77.34 \mathrm{E})$ & North & 14.2 & 13.0 & -1.2 \\
\hline Madurai & $(10.19 \mathrm{~N}, 79.23 \mathrm{E})$ & South & 35.0 & 33.5 & -1.5 \\
\hline Chennai & $(14.05 \mathrm{~N}, 80.29 \mathrm{E})$ & Plain & 16.6 & 17.4 & 0.8 \\
\hline Bangalore & $(13.92 \mathrm{~N}, 77.12 \mathrm{E})$ & Mountainous area & 33.2 & 32.9 & -0.3 \\
\hline Visakhapatnam & $(18.90 \mathrm{~N}, 83.28 \mathrm{E})$ & Coastal area & 30.9 & 30.3 & -0.6 \\
\hline Hyderabad & $(18.23 \mathrm{~N}, 78.27 \mathrm{E})$ & Inland & 32.8 & 32.7 & -0.1 \\
\hline
\end{tabular}

Note: The historical data come from http://sdwebx.worldbank.org/climateportal/index.cfm.

differences of latent heat flux and sensible heat flux between 2010 and 2050. The reclamation of cultivated land may change the land cover, and the land cover change may further lead to changes in surface heat flux $[5,19]$. The annual average difference shows that there is some change in the distribution of the surface heat flux between the latent heat flux and the sensible heat flux; the latent heat flux increases by $0.84 \mathrm{~W} / \mathrm{m}^{2}$ while the sensible heat flux decreases by $1.03 \mathrm{~W} / \mathrm{m}^{2}$, which might lead to the decrease in the near-surface temperature in India.

The simulation result indicates that there is obvious seasonal fluctuation of these fluxes (Table 3). For example, the latent heat flux in the monsoon season (roughly from August to October) increases by $0.73 \mathrm{~W} / \mathrm{m}^{2}$ on average, while the sensible heat flux decreases by $0.90 \mathrm{~W} / \mathrm{m}^{2}$ on average. By comparison, the latent heat flux before the monsoon season (roughly from April to July) increases by $1.56 \mathrm{~W} / \mathrm{m}^{2}$ on average, while the sensible heat flux decreases by $1.72 \mathrm{~W} / \mathrm{m}^{2}$ on average, which indicated that the changes on these fluxes before the monsoon season are larger than that in the monsoon season. Most of the cultivated land in India depends on the provision of the water source by the irrigation, and there is limited precipitation before the monsoon season. So the evapotranspiration in the cultivated land before the monsoon season is much higher than that in other land cover types, which may enhance the change on the distribution of the surface heat flux between the latent heat flux and sensible heat flux above the new cultivated land, while in the monsoon season the sufficient precipitation increases the soil moisture in all land cover types and makes the evapotranspiration in other land cover types be similar to that in the cultivated land, which relatively weakens the impacts of the reclamation of cultivated land on the energy.

\subsection{Possible Impacts of the Cultivated Land Reclamation on Air Temperature}

3.4.1. Overall Conditions of the Near-Surface Temperature. Since the near-surface temperature is the most extreme in the summer and winter, we have mainly focused on the forecast of the monthly average temperature in the summer and winter with the simulation of the cultivated land reclamation for the study area of India. The spatial heterogeneity of the monthly average temperature in the summer and winter from 2010 to 2050 is shown in Figure 3. The result indicates that the future reclamation of cultivated land in India will have some impacts on the monthly average temperature in the summer and winter. In comparison to the base year 2010, it will make the monthly average temperature of the summer in India in 2050 decrease by $0.22^{\circ} \mathrm{C}$ and that of the winter increase by $0.11^{\circ} \mathrm{C}$. And it has cooling effect on the temperature in India on the whole, which is different from the results of researches only focusing on irrigation [35, 45] or deforestation [29], but it is consistent with the conclusion of Feddema et al. [27] that agriculture expansion can contribute to the decrease in the daytime temperature at the low or middle latitudes. This may be because some other land use types will be converted into the irrigated cropland during the reclamation of cultivated land in India; the increased irrigation plays an important role in decreasing the temperature. Besides, the conversion of grasslands or forests into the dryland cropland can increase the sensible heat of the land surface, decrease the latent heat and evapotranspiration, and consequently make the monthly average temperature increase. In addition, the combined effects of the conversion of various other land use types into the cropland may make the overall climatic effect very different.

Our simulation results indicate the temperature change also varies with spatial locations. In the summer, the monthly average temperature in most regions of India decreases to some degree, among which it decreases most significantly in Gangetic Plain in the north part, with the decrement of $0.70^{\circ} \mathrm{C}$; as this region has good irrigation conditions, the newly reclaimed cultivated land can be irrigated which consequently makes the cultivated land play an important role in decreasing the temperature, which is consistent with the conclusions of Feddema et al. [27] and Mao et al. [35]. The temperature has not changed that much in some parts of the Eastern Ghats Mountain and the Western Ghats Mountain where the altitude is relatively high. And the temperature shows an increasing trend in the regions along Himalayas Mountain and the area to the west of Western Ghats Mountain, with an increment of $0.57^{\circ} \mathrm{C}$. In the winter, the monthly average temperature increases to some degree in most parts of India (approximately $64.52 \%$ of the study area) due to the reclamation of cultivated land. These regions are mainly located in the plateaus with a high altitude and part of the plain area, where there is very limited agricultural irrigation in the winter and the reclamation of cultivated land has limited effects on the temperature fall. However, the conversion of forests and so forth into the cultivated land in these regions may decrease the vegetation coverage, change the latent heat flux and sensible heat flux, and consequently 
TABLE 3: Projected differences of monthly and annual heat fluxes between 2010 and 2050 in India.

\begin{tabular}{|c|c|c|c|c|c|c|c|c|c|c|c|c|c|}
\hline & Jan & $\mathrm{Feb}$ & Mar & Apr & May & Jun & Jul & Aug & Sep & Oct & Nov & Dec & Yearly average \\
\hline Latent heat flux $\left(\mathrm{W} / \mathrm{m}^{2}\right)$ & 0.14 & 0.54 & 0.68 & 1.80 & 1.06 & 1.40 & 1.99 & 0.47 & 1.50 & 0.23 & 0.18 & 0.11 & 0.84 \\
\hline Sensible heat flux $\left(\mathrm{W} / \mathrm{m}^{2}\right)$ & -0.42 & -0.78 & -0.95 & -2.00 & -1.17 & -1.54 & -2.18 & -0.64 & -1.61 & -0.45 & -0.33 & -0.29 & -1.03 \\
\hline
\end{tabular}

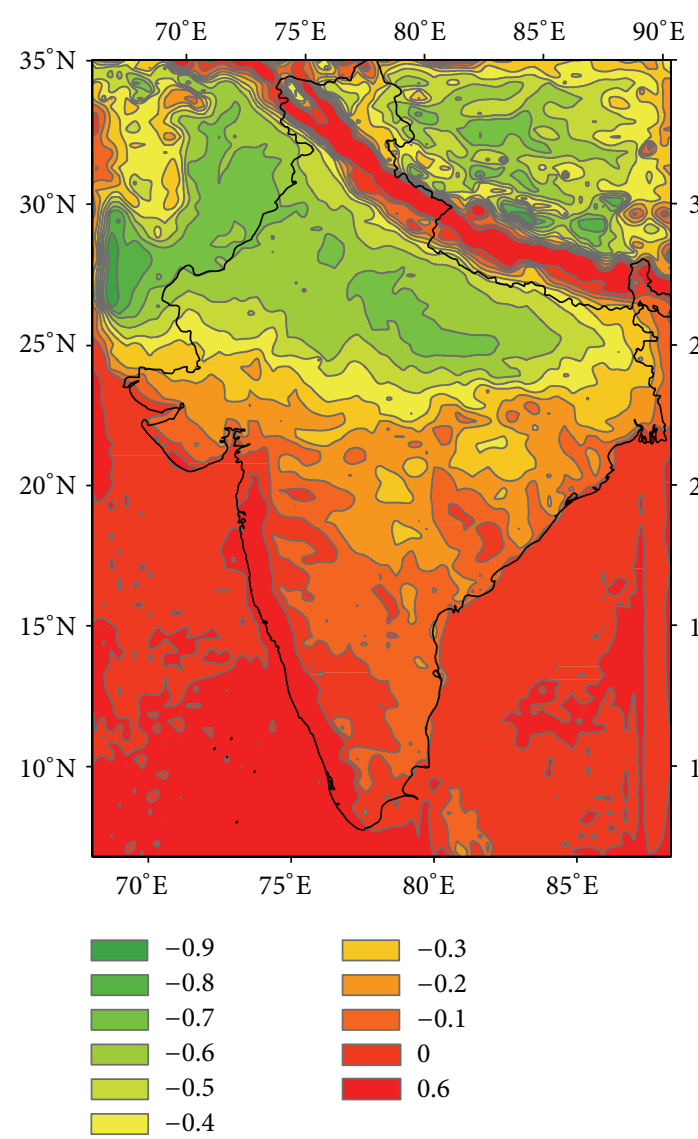

(a)

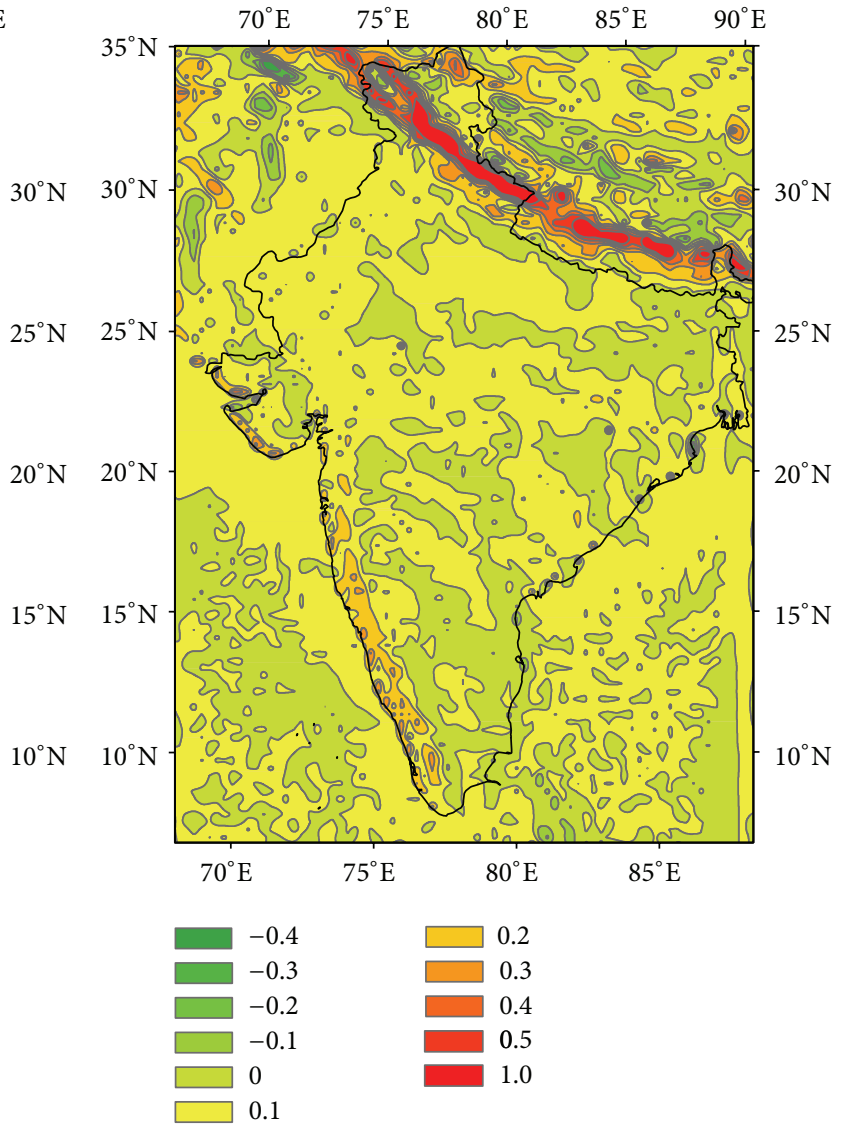

(b)

FIGURE 3: Change of the monthly average temperature in the summer (a) and the winter (b) due to the cultivated land reclamation in India.

make the temperature increase [9]. Besides, the monthly average temperature keeps stable in approximately $35.15 \%$ of the whole region of the study area, mainly in the plain area where the altitude is relatively low. In addition, the monthly average temperature shows a decreasing trend in only $0.32 \%$ of the whole region, which is sparsely distributed in some area near Himalayas Mountain. In summary, there is obvious seasonal change of the impacts of the reclamation of cultivated land in India on the monthly average temperature. Meanwhile, the regions with the temperature change is much wider than the regions with reclamation of cultivated land, indicating that the reclamation of cultivated land influences not only the local climate but also the regional climate in the neighboring districts (Figure 3).

3.4.2. Relationship between LUCC and the Changes of NearSurface Temperature. We quantitatively analyzed the relationship between the monthly average temperature and
LUCC caused by reclamation. The results show that the changes from evergreen broadleaf forest to irrigated cropland and pasture (designated as the conversion of 13 to 3 for brevity; the same below) or the changes from mixed forest to irrigated cropland and pasture (15 to 3 ) will cause an increase in the monthly average temperature separately by $0.31^{\circ} \mathrm{C}$ and $0.21^{\circ} \mathrm{C}$ in summer (Figure 4(a)). These two types of reclamation can cause a decrease in latent heat flux and an increase in sensible heat flux, leading to an increase on land surface temperature. The increase in temperature causing by the decrease in forest will be larger than the decrease in temperature causing by cropland irrigation in this case. In addition to these two types of cultivated land reclamation, other types have cooling effect on the surface temperature, among which, the conversion from barren or sparsely vegetated to irrigated cropland and pasture (19 to 3 ) will lead to a maximum decrease in the monthly average temperature (i.e., $-0.40^{\circ} \mathrm{C}$ ); this is because there is little vegetation in the initial types of land; while they are converted 


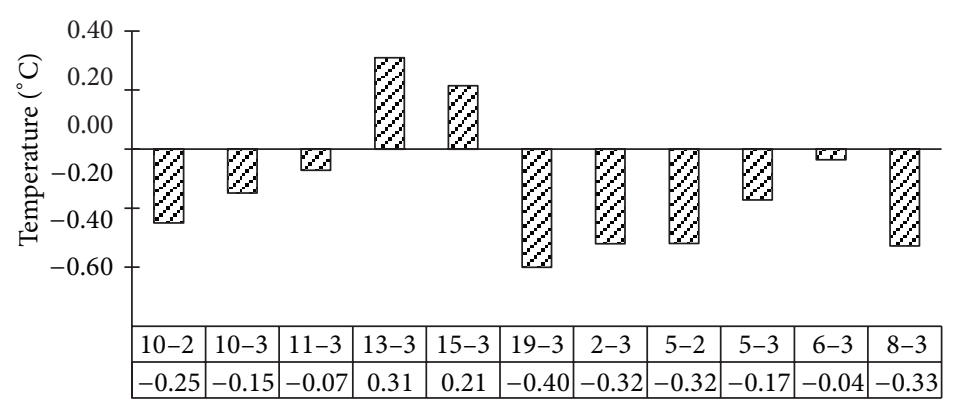

(a)

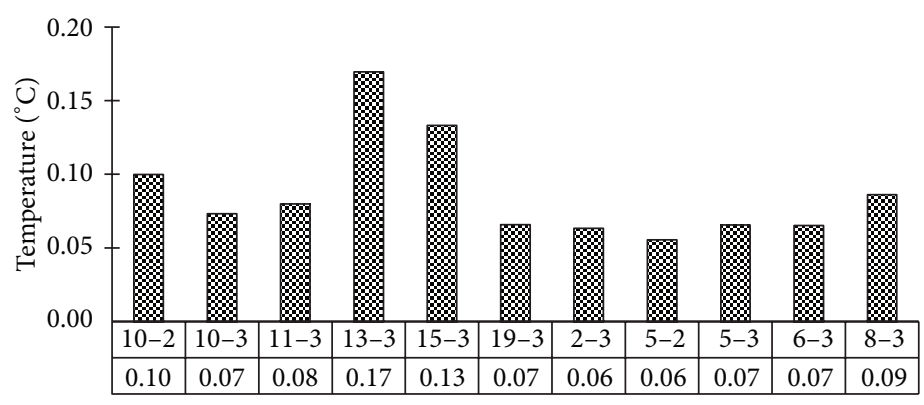
2: Dryland cropland and pasture
3: Irrigated cropland and pasture
5: Cropland/grassland mosaic
6: Cropland/woodland mosaic
8: Shrubland

10: Savanna
11: Deciduous broadleaf forest
13: Evergreen broadleaf forest
15: Mixed forest
19: Barren or sparsely vegetated

(b)

FIGURE 4: Change of the monthly average temperature of different types of LUCC in the future reclamation of cultivated land in the summer (a) and the winter (b). Note: $i-j(i, j$ are codes of land use/cover types) refers to the conversion from the land use/cover of $i$ to that of $j$.

into irrigated cropland and pasture, latent heat flux would be increased and sensible heat flux decreased, so the monthly average temperature is reduced. And the cooling effect of conversion from cropland/woodland mosaic to irrigated cropland and pasture ( 6 to 3 ) is the least (i.e., $-0.04^{\circ} \mathrm{C}$ ). In winter (Figure 4(b)), different types of reclamation will cause an universal rise on the monthly average temperature, among which, the conversion from evergreen broadleaf forest to irrigated cropland (13 to 3) will lead to a maximum increase in the monthly average temperature (i.e., $0.17^{\circ} \mathrm{C}$ ).

The results above indicate that the effects of cultivated land reclamation on temperature vary between seasons. Meanwhile, the impacts of different cultivated land reclamation types on temperature are also different, this is because different types of cultivated land reclamation will lead to different changes in vegetation types and farmland management modes, which will result in change of latent heat flux and sensible heat flux and thus lead to different temperature effect indirectly.

\section{Conclusions and Discussion}

After testing and verifying the ability of the WRF model in simulating the temperature of India, we updated the static land cover data in the WRF and simulated the possible impacts of cultivated land reclamation on the temperature in
India. India has vast cultivated land reclaimed for agricultural production; there is, however, still a trend of reclamation of cultivated land in the future since the population growth leads the increasing grain demand. The area of LUCC due to the reclamation of cultivated land is projected to reach 1.16 million $\mathrm{km}^{2}$, among which, around 584.33 thousand $\mathrm{km}^{2}$ of the dryland cropland will be converted into the irrigated cropland, and nearly 560.12 thousand $\mathrm{km}^{2}$ of other land use types will be converted into irrigated cropland, accounting for $50.23 \%$ and $48.15 \%$ of the total conversion area, respectively. The proportion of cultivated land and pasture in the study area will increase from $73.03 \%$ to $85.28 \%$.

The result of the model verification indicates that the WRF model can well reflect the seasonal change and spatial pattern of the temperature in India, although there is some difference between the simulated and observed values, with the simulated temperature being a bit lower on the whole. The simulation result in six representative cities indicates that there is no significant difference between the spatial pattern of the simulated and observed values in most regions, suggesting that the WRF model has great advantage in simulating the climate in India.

There is some change in the distribution between the latent heat flux and sensible heat flux; the latent heat flux will increase, while the sensible heat flux will decrease, which may be a reason for the decreasing trend of the monthly average 
temperature in India on the whole. Besides, there are some variations on the heat flux changes in different seasons.

The cultivated land reclamation has obvious seasonal impacts on the climate in India. It mainly decreases the temperature in the summer, while it increases the temperature in the winter. Since the different types of reclamation of cultivated land involve different types of LUCC and cropland management modes, there will be some differences in the change of the geophysical parameters such as latent heat flux and sensible heat flux, which will subsequently lead to different effects on the near-surface temperature. Besides, the reclamation of cultivated land influences not only the local climate but also the regional climate in the neighboring districts.

This study is still preliminary, and there are some uncertainties and problems to be further solved on the climatic effects of the LUCC in the research; further study should be carried out. For example, there are many factors that influence the regional climate and they generally act synthetically, so more factors should be taken into account. Besides, the reclamation of cultivated land in India also influences many climatic factors, some of which have not been taken into account in this study, so there may be some uncertainties and it is necessary to complement the sensitivity analysis in the forthcoming researches.

\section{Conflict of Interests}

The authors declare that there is no conflict of interests regarding the publication of this paper.

\section{Acknowledgments}

This research was supported by the Key Project funded by the Chinese Academy of Sciences (no. KZZD-EW-08), the National Key Program for Developing Basic Science in China (no. 2010CB950900), and the External Cooperation Program of the Chinese Academy of Sciences (no. GJHZ1312).

\section{References}

[1] R. A. Pielke Sr., "Land use and climate change," Science, vol. 310, no. 5754, pp. 1625-1626, 2005.

[2] L. Bounoua, R. DeFries, G. J. Collatz, P. Sellers, and H. Khan, "Effects of land cover conversion on surface climate," Climatic Change, vol. 52, no. 1-2, pp. 29-64, 2002.

[3] J. Jin, S. Lu, S. Li, and N. L. Miller, "Impact of land use change on the local climate over the Tibetan Plateau," Advances in Meteorology, vol. 2010, Article ID 837480, 6 pages, 2010.

[4] T. Zhang, J. Zhan, F. Wu, J. Luo, and J. Huang, "Regional climate variability responses to future land surface forcing in the Brazilian Amazon," Advances in Meteorology, vol. 2013, Article ID 852541, 9 pages, 2013.

[5] X. Deng, C. Zhao, and H. Yan, "Systematic modeling of impacts of land use and land cover changes on regional climate: a review," Advances in Meteorology, vol. 2013, Article ID 317678, 11 pages, 2013.

[6] R. A. Pielke Sr., G. Marland, R. A. Betts et al., "The influence of land-use change and landscape dynamics on the climate system: relevance to climate-change policy beyond the radiative effect of greenhouse gases," Philosophical Transactions of the Royal Society A, vol. 360, no. 1797, pp. 1705-1719, 2002.

[7] L. J. Gordon, W. Steffen, B. F. Jönsson, C. Folke, M. Falkenmark, and Å. Johannessen, "Human modification of global water vapor flows from the land surface," Proceedings of the National Academy of Sciences of the United States of America, vol. 102, no. 21, pp. 7612-7617, 2005.

[8] R. Mahmood, S. A. Foster, T. Keeling, K. G. Hubbard, C. Carlson, and R. Leeper, "Impacts of irrigation on 20th century temperature in the northern Great Plains," Global and Planetary Change, vol. 54, no. 1-2, pp. 1-18, 2006.

[9] R. A. Betts, P. D. Falloon, K. K. Goldewijk, and N. Ramankutty, "Biogeophysical effects of land use on climate: model simulations of radiative forcing and large-scale temperature change," Agricultural and Forest Meteorology, vol. 142, no. 2-4, pp. 216233, 2007.

[10] T. Loveland, R. Mahmood, T. Patel-Weynand et al., "National climate assessment technical report on the impacts of climate and land use and land cover change," US Geological Survey Open-File Report, vol. 1155, p. 87, 2012.

[11] R. Qu, X. Cui, H. Yan, E. Ma, and J. Zhan, "Impacts of land cover change on the near-surface temperature in the North China Plain," Advances in Meteorology, vol. 2013, Article ID 409302, 12 pages, 2013.

[12] Q. Shi, Y. Lin, E. Zhang, H. Yan, and J. Zhan, "Impacts of cultivated land reclamation on the climate and grain production in Northeast China in the future 30 years," Advances in Meteorology, vol. 2013, Article ID 853098, 8 pages, 2013.

[13] J. Y. Liu and X. Z. Deng, "Progress of the research methodologies on the temporal and spatial process of LUCC," Chinese Science Bulletin, vol. 55, no. 14, pp. 1354-1362, 2010.

[14] J. Zhan, N. Shi, S. He, and Y. Lin, "Factors and mechanism driving the land-use conversion in Jiangxi Province," Journal of Geographical Sciences, vol. 20, no. 4, pp. 525-539, 2010.

[15] L. Jiang, X. Deng, and K. C. Seto, "Multi-level modeling of urban expansion and cultivated land conversion for urban hotspot counties in China," Landscape and Urban Planning, vol. 108, no. 2-4, pp. 131-139, 2012.

[16] J. Liu, J. Zhan, and X. Deng, "Spatio-temporal patterns and driving forces of urban land expansion in China during the economic reform era," Ambio, vol. 34, no. 6, pp. 450-455, 2005.

[17] X. Deng, J. Huang, E. Uchida, S. Rozelle, and J. Gibson, "Pressure cookers or pressure valves: do roads lead to deforestation in China?" Journal of Environmental Economics and Management, vol. 61, no. 1, pp. 79-94, 2011.

[18] Q. Jiang, X. Deng, J. Zhan, and S. He, "Estimation of land production and its response to cultivated land conversion in North China Plain," Chinese Geographical Science, vol. 21, no. 6, pp. 685-694, 2011.

[19] J. Liu and X. Deng, "Influence of different land use on urban microenvironment in Beijing City, China," Journal of Food, Agriculture and Environment, vol. 9, no. 3-4, pp. 1005-1011, 2011.

[20] B. Güneralp and K. C. Seto, "Environmental impacts of urban growth from an integrated dynamic perspective: a case study of Shenzhen, South China," Global Environmental Change, vol. 18, no. 4, pp. 720-735, 2008.

[21] L. Jiang, X. Deng, and K. C. Seto, "The impact of urban expansion on agricultural land use intensity in China," Land Use Policy, vol. 35, pp. 33-39, 2013. 
[22] K. C. Seto, M. Fragkias, B. Güneralp, and M. K. Reilly, "A metaanalysis of global urban land expansion," PloS ONE, vol. 6, no. 8, Article ID e23777, 2011.

[23] Q. Jiang, X. Deng, H. Yan, D. Liu, and R. Qu, "Identification of food security in the mountainous guyuan prefecture of China by exploring changes of food production," Journal of Food, Agriculture and Environment, vol. 10, no. 1, pp. 210-216, 2012.

[24] X. Deng, Q. Jiang, J. Zhan, S. He, and Y. Lin, "Simulation on the dynamics of forest area changes in Northeast China," Journal of Geographical Sciences, vol. 20, no. 4, pp. 495-509, 2010.

[25] F. Wu, X. Deng, F. Yin, and Y. Yuan, "Projected changes of grassland productivity along the representative concentration pathways during 2010-2050 in China," Advances in Meteorology, vol. 2013, Article ID 812723, 9 pages, 2013.

[26] T. N. Chase, R. A. Pielke Sr., T. G. F. Kittel, R. R. Nemani, and S. W. Running, "Simulated impacts of historical land cover changes on global climate in northern winter," Climate Dynamics, vol. 16, no. 2-3, pp. 93-105, 2000.

[27] J. J. Feddema, K. W. Oleson, G. B. Bonan et al., "Atmospheric science: the importance of land-cover change in simulating future climates," Science, vol. 310, no. 5754, pp. 1674-1678, 2005.

[28] D. Werth and R. Avissar, "The local and global effects of Amazon deforestation," Journal of Geophysical Research, vol. 107, no. 20, pp. LBA 55-1-LBA 55-8, 2002.

[29] G. Bala, K. Caldeira, M. Wickett et al., "Combined climate and carbon-cycle effects of large-scale deforestation," Proceedings of the National Academy of Sciences of the United States of America, vol. 104, no. 16, pp. 6550-6555, 2007.

[30] D. Niyogi, H.-I. Chang, F. Chen et al., "Potential impacts of aerosol-land-atmosphere interactions on the Indian monsoonal rainfall characteristics," Natural Hazards, vol. 42, no. 2, pp. 345359, 2007.

[31] E. M. Douglas, A. Beltrán-Przekurat, D. Niyogi, R. A. Pielke Sr., and C. J. Vörösmarty, "The impact of agricultural intensification and irrigation on land-atmosphere interactions and Indian monsoon precipitation-a mesoscale modeling perspective," Global and Planetary Change, vol. 67, no. 1-2, pp. 117-128, 2009.

[32] D. B. Lobell, G. Bala, and P. B. Duffy, "Biogeophysical impacts of cropland management changes on climate," Geophysical Research Letters, vol. 33, no. 6, Article ID L06708, 2006.

[33] I. Haddeland, D. P. Lettenmaier, and T. Skaugen, "Effects of irrigation on the water and energy balances of the Colorado and Mekong river basins," Journal of Hydrology, vol. 324, no. 1-4, pp. 210-223, 2006.

[34] R. Kunzig, "Population 7 billion," National Geographic, vol. 219, no. 1, pp. 32-63, 2011.

[35] H. Mao, X. Yan, Z. Xiong, and H. Tian, "Modeled impact of irrigation on regional climate in India," Acta Ecologica Sinica, vol. 31, no. 4, pp. 1038-1045, 2011.

[36] J. Jin, N. L. Miller, and N. Schlegel, "Sensitivity study of four land surface schemes in the WRF model," Advances in Meteorology, vol. 2010, Article ID 167436, 11 pages, 2010.

[37] B. Storm, J. Dudhia, S. Basu, A. Swift, and I. Giammanco, "Evaluation of the weather research and forecasting model on forecasting low-level jets: implications for wind energy," Wind Energy, vol. 12, no. 1, pp. 81-90, 2009.

[38] J. G. Powers, "Numerical prediction of an Antarctic severe wind event with the Weather Research and Forecasting (WRF) model," Monthly Weather Review, vol. 135, no. 9, pp. 3134-3157, 2007.
[39] M. B. Ek, K. E. Mitchell, Y. Lin et al., "Implementation of Noah land surface model advances in the National Centers for Environmental Prediction operational mesoscale Eta model," Journal of Geophysical Research D, vol. 108, no. 22, pp. 1-16, 2003.

[40] A. Gettelman, H. Morrison, and S. J. Ghan, "A new two-moment bulk stratiform cloud microphysics scheme in the community atmosphere model, version 3 (CAM3). Part II: single-column and global results," Journal of Climate, vol. 21, no. 15, pp. 3660 3679, 2008.

[41] V. S. Challa, J. Indracanti, M. K. Rabarison et al., "A simulation study of mesoscale coastal circulations in Mississippi Gulf coast," Atmospheric Research, vol. 91, no. 1, pp. 9-25, 2009.

[42] G. A. Grell and D. Dévényi, "A generalized approach to parameterizing convection combining ensemble and data assimilation techniques," Geophysical Research Letters, vol. 29, no. 14, pp. 38$1,2002$.

[43] S.-Y. Hong, Y. Noh, and J. Dudhia, "A new vertical diffusion package with an explicit treatment of entrainment processes," Monthly Weather Review, vol. 134, no. 9, pp. 2318-2341, 2006.

[44] J. Fujino, R. Nair, M. Kainuma, T. Masui, and Y. Matsuoka, "Multi-gas mitigation analysis on stabilization scenarios using aim global model," Energy Journal, vol. 27, pp. 343-353, 2006.

[45] E. Lee, T. N. Chase, B. Rajagopalan, R. G. Barry, T. W. Biggs, and P. J. Lawrence, "Effects of irrigation and vegetation activity on early Indian summer monsoon variability," International Journal of Climatology, vol. 29, no. 4, pp. 573-581, 2009. 

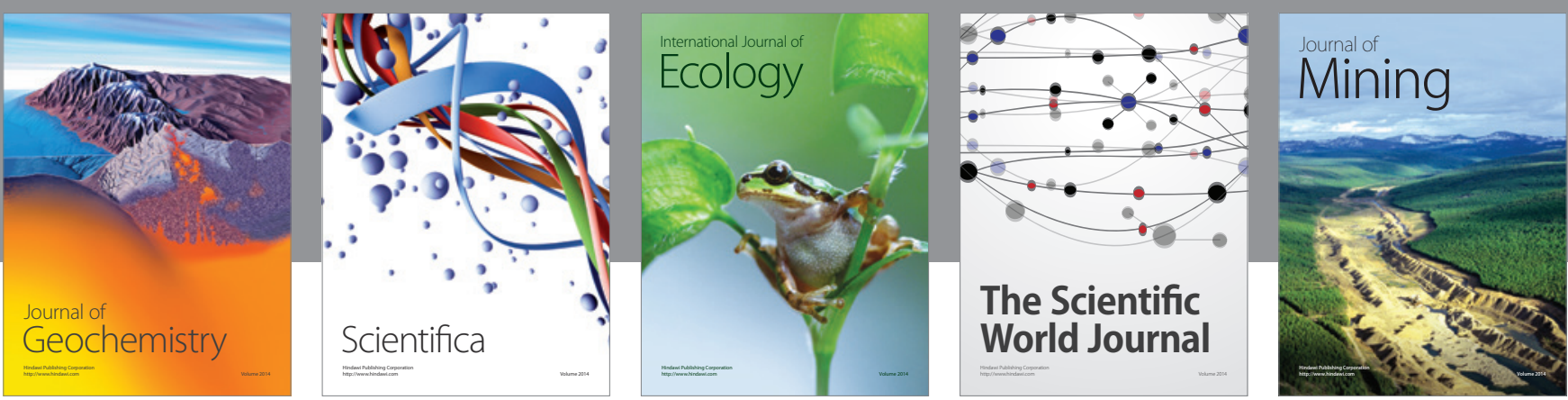

The Scientific World Journal
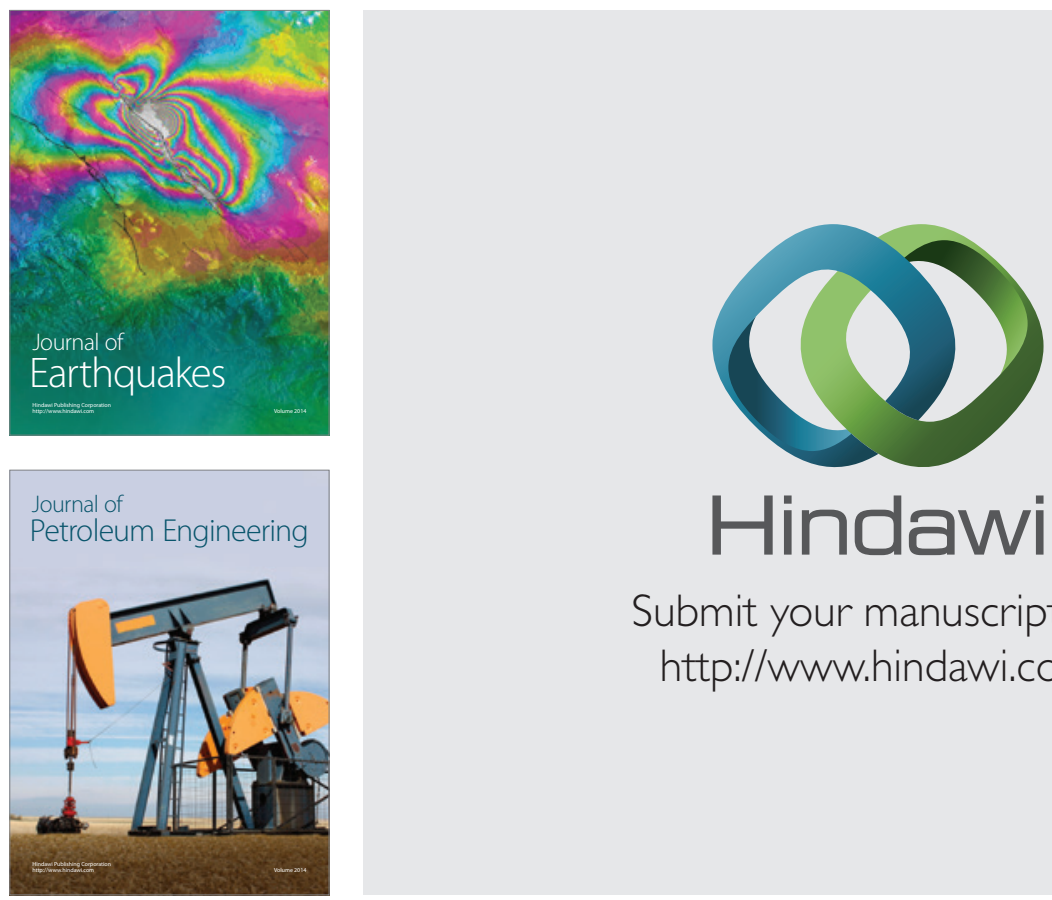

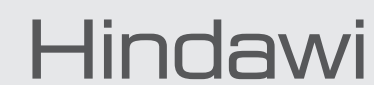

Submit your manuscripts at

http://www.hindawi.com
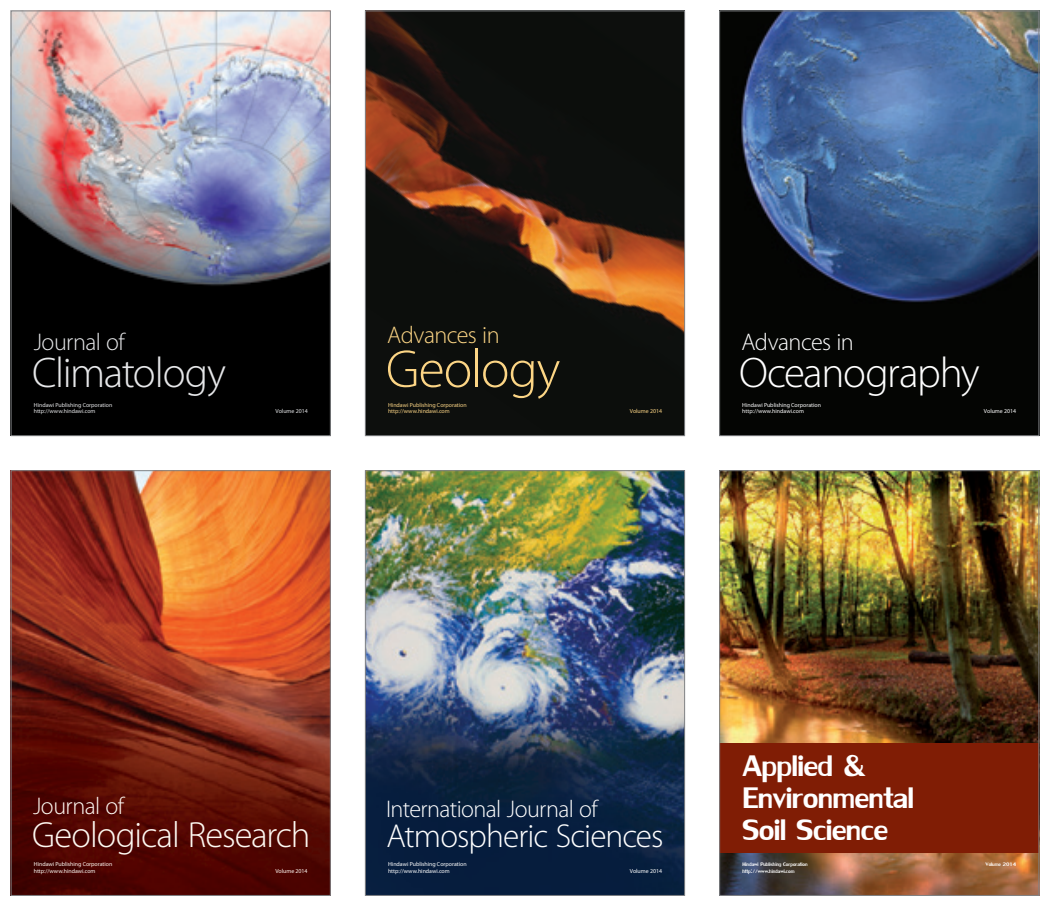
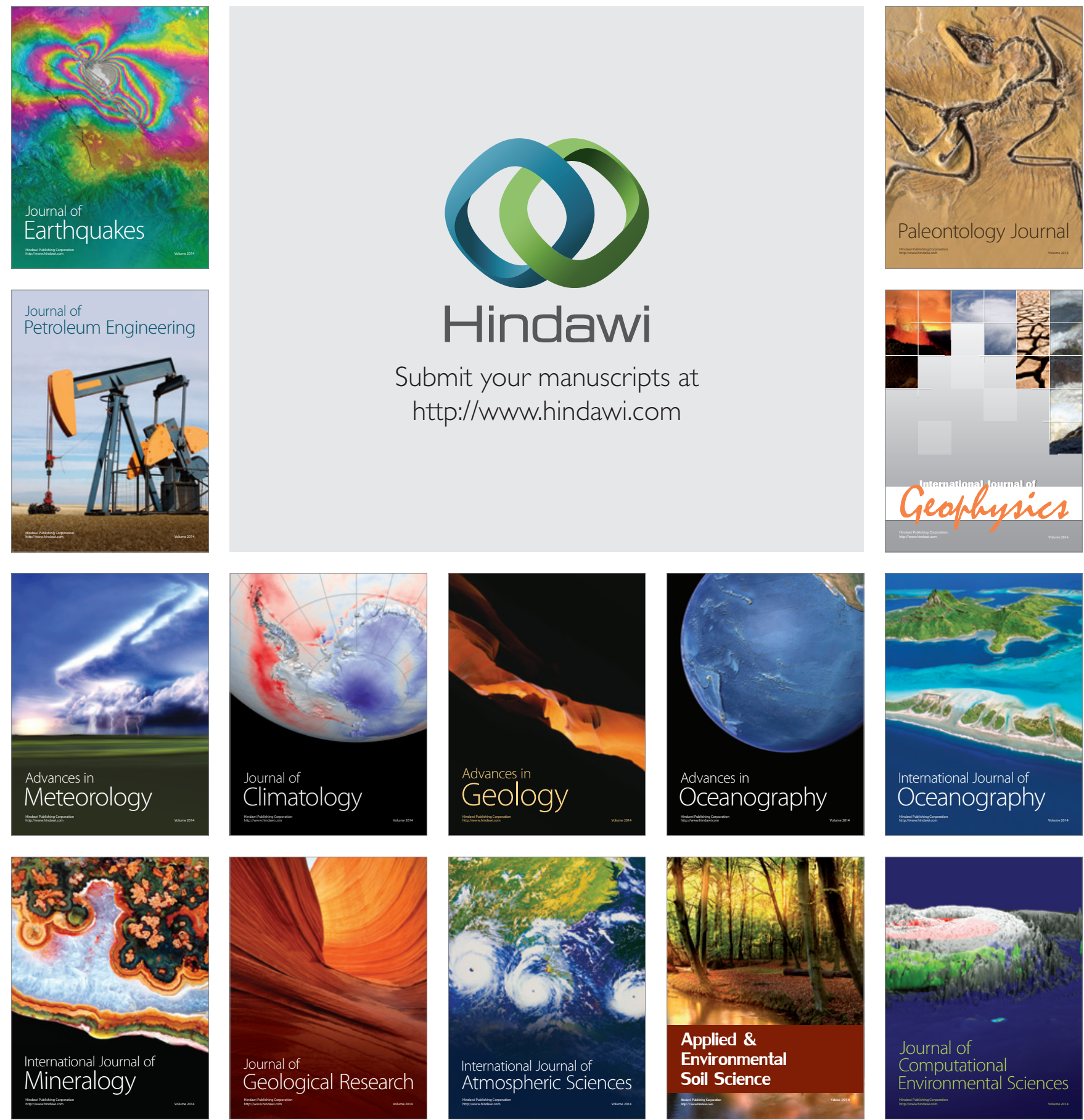